\title{
Computer Tools for Diagnosing Citrus Leaf Symptoms (Part 1): Diagnosis and Recommendation Integrated System (DRIS) ${ }^{1}$
}

Arnold Schumann ${ }^{2}$

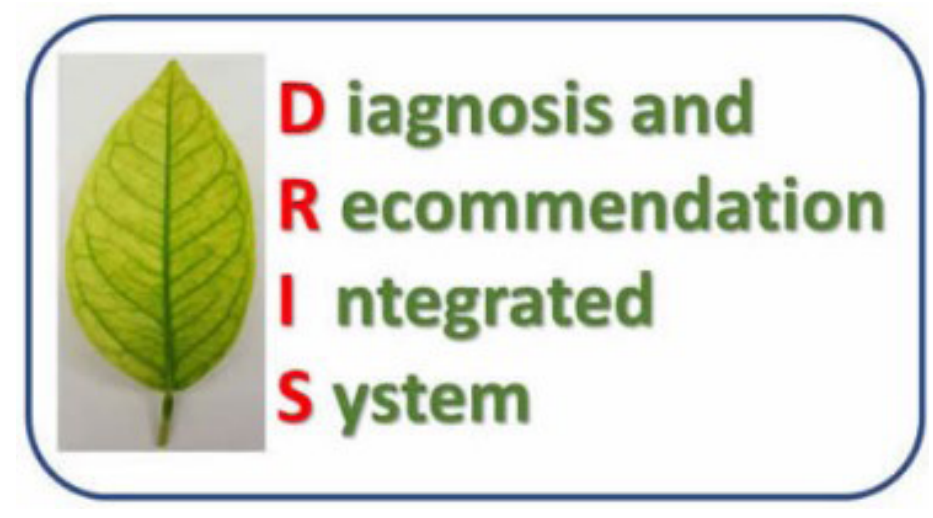

This web-based deployment of DRIS is designed for analyzing leaf nutrient concentrations of Florida citrus. It has been optimized for Florida oranges (and related varieties), and the DRIS norms used for calculations were derived from a high-yielding 'Hamlin' orange grove in the central Florida Ridge region prior to the spread of greening disease (huanglongbing, HLB). Because varieties like grapefruit have lower $\mathrm{N}$ requirements than oranges, the DRIS results for grapefruit may be less useful. The main goal of the DRIS web app is to provide greater depth of interpretation for leaf nutrient concentrations in the HLB era. Specifically, DRIS can rank nutrient deficiencies and excesses in order of severity and identify "hidden hunger" or nutrient imbalances. The DRIS web app, publications, and instructions are available at www.makecitrusgreatagain.com. A summary is provided below.

To use this tool, prepare an Excel file with your leaf nutrient data according to the template provided: CitrusDRISexample.csv. The nutrients should appear in the following order and with these units (left to right): $\% \mathrm{~N} \% \mathrm{P} \% \mathrm{~K}$ $\% \mathrm{Mg} \% \mathrm{Ca} \% \mathrm{~S} \mathrm{~B}$ (ppm) Zn (ppm) Mn (ppm) Fe (ppm) Cu (ppm). Include the single line heading and a left column for sample identity, as shown. You can add many more line records to the file as required. When done, save the file as a "comma-separated-values" (.csv) file. To start the analysis, follow the instructions by uploading the data .csv file; you will receive the DRIS results in another .csv file, which you can open and read in Excel. If you encounter an error message, it means that the data file is incorrectly formatted, has missing values, or has unexpected characters (e.g., an $\mathrm{O}$ instead of a 0). Correct the data file and retry.

\begin{tabular}{|c|c|c|c|c|c|c|c|c|c|c|c|c|}
\hline 4 & A & B & c & D & E & $F$ & G & H & 1 & J & k & L \\
\hline 1 & Sample & $\% \mathrm{~N}$ & $\% \mathrm{P}$ & $\% \mathrm{~K}$ & $\% \mathrm{Mg}$ & $\% \mathrm{Ca}$ & $\% s$ & $\mathrm{~B}(\mathrm{ppm})$ & $\mathrm{Zn}(\mathrm{ppm}) \mathrm{n}$ & $\mathrm{Mn}(\mathrm{ppm})$ & $\mathrm{Fe}(p p m)$ & $\mathrm{Cu}(\mathrm{ppm})$ \\
\hline 2 & 1 & 2.31 & 0.21 & 1.48 & 0.25 & 2.64 & 0.28 & 136.5 & 22.67 & 113.9 & 48.39 & 40.7 \\
\hline 3 & 2 & 2.1 & 0.29 & 1.15 & 0.25 & 2.81 & 0.28 & 88.91 & 12.73 & 80.01 & 43.21 & 28.58 \\
\hline 4 & 3 & 2.37 & 0.35 & 1.26 & 0.24 & 2.95 & 0.36 & 122.5 & 14.78 & 93.57 & 46.2 & 37.44 \\
\hline 5 & 4 & 2.61 & 0.16 & 1.49 & 0.37 & 3.59 & 0.37 & 49.92 & 25.37 & 30.3 & 75.11 & 9.17 \\
\hline 6 & 5 & 2.58 & 0.15 & 1.49 & 0.43 & 3.68 & 0.37 & 60.6 & 36.28 & 31.21 & 93.13 & 15 \\
\hline 7 & 6 & 2.98 & 0.16 & 1.77 & 0.34 & 3.33 & 0.3 & 74.32 & 49.88 & 29.16 & 70.78 & 13.03 \\
\hline 8 & 7 & 3.16 & 0.16 & 1.39 & 0.37 & 3.58 & 0.32 & 75.45 & 48.35 & 31.82 & 74.4 & 16.63 \\
\hline 9 & & & & & & & & & & & & \\
\hline
\end{tabular}

1. This document is SL470, one of a series of the Department of Soil and Water Sciences, UF/IFAS Extension. Original publication date August 2020. Visit the EDIS website at https://edis.ifas.ufl.edu for the currently supported version of this publication.

2. Arnold Schumann, professor, Department of Soil and Water Sciences, UF/IFAS Citrus Research and Education Center, Lake Alfred, FL 33850.

The Institute of Food and Agricultural Sciences (IFAS) is an Equal Opportunity Institution authorized to provide research, educational information and other services

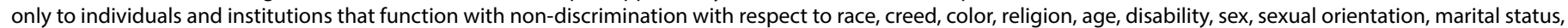

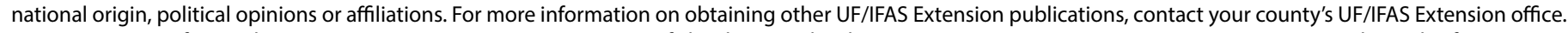
U.S. Department of Agriculture, UF/IFAS Extension Service, University of Florida, IFAS, Florida A \& M University Cooperative Extension Program, and Boards of County Commissioners Cooperating. Nick T. Place, dean for UF/IFAS Extension. 


\section{Interpretation}

DRIS results consist of a nutrient index for each nutrient and an index for "dry mass" (DM). Indices range in value from negative (deficient or low) to near zero (optimum) to more positive (high or excessive). The magnitudes of the indices reflect the relative severity of the nutrient imbalance. An aggregate absolute value of all the indices is the Nutrient Balance Index (NBI), in which a lower value indicates more balanced tree nutrition. The diagnosis column lists the nutrients that are classified "deficient," "low," "high," or "excess" according to EDIS publication SL253, Nutrition of Florida Citrus Trees, $3^{\text {rd }}$ Edition (https://edis.ifas.ufl. $\mathrm{edu} / \mathrm{ss} 478)$. Moreover, the nutrients listed are ranked in order of decreasing severity (left to right). In the HLB era, this information is particularly useful because it can help prioritize the most appropriate corrective fertilization.

NOTE: If you want to exclude a nutrient element from DRIS analysis, enter a zero (0) in the data file. For example, a lab may not provide sulfur $(S)$ in the report. It is important to keep the format of the data file the same; even if you do not have data for $S$, you should still include the $S$ data column with all zeros.

\section{References}

Beaufils, E. R. 1973. "Diagnosis and Recommendation Integrated System (DRIS)." Soil Science Bull. No. 1, University of Natal, S. Africa

Morgan, K. T., and D. Kadyampakeni, eds. 2020. Nutrition of Florida Citrus Trees, $3^{\text {rd }}$ Edition. SL253. Gainesville: University of Florida Institute of Food and Agricultural Sciences. https://edis.ifas.ufl.edu/ss478

Schumann, A. W. 2009. "Potential Use of DRIS for Leaf Nutrient Diagnosis in Florida Citrus." Citrus Industry 90:4.

Schumann, A. W. 2019. "Critical Leaf Nutrient Thresholds to Diagnose Deficiencies in HLB Trees." Citrus Industry 100:4

Walworth, J. L., and M. E. Sumner. 1987. "The Diagnosis and Recommendation Integrated System (DRIS)." In Advances in Soil Science vol. 6, edited by B. A. Stewart. New York City: Springer. 